\title{
PENGAWETAN KAYU TISUK (Hibiscus macrophyllus Roxb.) MELALUI RENDAMAN DINGIN DENGAN BAHAN PENGAWET BORIC ACID EQUIVALENT \\ (Tisuk (Hibiscus macrophyllus Roxb.) Wood Preservation Using Boric Acid Equivalent with Cold Immersion Method)
}

\author{
Endah Suhaendah \& M. Siarudin \\ Balai Penelitian Teknologi Agroforestry \\ Jl. Raya Ciamis -Banjar Km. 11, Ciamis 46201 \\ e-mail:msiarudin@yahoo.com
}

Diterima 11 Februari 2013, Disetujui 5 Februari 2014

\begin{abstract}
Tisuk (Hibiscus macrophyllus Roxb.) is one of fast growing tree species widely planted in private forest mainly in Java Island. However one of the weaknesses of tisuk wood is the low durability which is categorized as durability class of III/IV. This paper studies the durability improvement of tisuk wood using Boric Acid Equivalent (BAE) with cold immersion method. The tisuk wood samples were taken from a private forest in Sukamulih Village, Sariwangi Subdistrict, Tasikmalaya Regency. The treatments applied were wood thickness (thickness of $2.5 \mathrm{~cm}, 5 \mathrm{~cm}, 7.5 \mathrm{~cm}$ and 10 $\mathrm{cm}$ ); immersion time (3 days, 5 days and 7 days); and two preservative concentration (5\% and 10\%). Each treatment was replicated in 10 specimens (total of 240 specimens). The parameters measured were the retention and penetration of preservative solutions. The analysis of variance shows that the retention of the preservative solutions was significantly different for the wood thickness treatment but it was not significant for other treatments (immersion time and preservative concentration). Meanwbile, the penetration of the preservative solutions was not significantly different for all of the treatments. The retention and penetration of the preservative solution fulfilled the minimum standard required by Indonesian National Standard for wood preservation in all treatments. Based on the analysis, the wood preservation method recommended for tisuk wood using boron and boric acid solutions is 3 days of duration of immersion with concentration of $5 \%$ for all of wood thickness treatments $(2.5 \mathrm{~cm}, 5 \mathrm{~cm}, 7.5 \mathrm{~cm}$ and $10 \mathrm{~cm})$.
\end{abstract}

Keywords: Retention, penetration, cold immersion, tisuk, woodpreservation

\begin{abstract}
ABSTRAK
Tisuk (Hibiscus macrophyllus Roxb.) adalah salah satu jenis tanaman cepat tumbuh yang banyak dikembangkan di hutan rakyat, terutama di Pulau Jawa. Salah satu kelemahan jenis ini adalah tingkat keawetannya yang rendah (kelas awet III/IV). Dalam rangka meningkatkan masa pakai kayu tisuk, penelitian mengenai pengawetan kayu tisuk dengan larutan Boric Acid Equivalent (BAE) melalui perendaman dingin telah dilakukan. Sampel kayu tisuk berasal dari hutan rakyat di Desa Sukamulih, Kecamatan Sariwangi, Kabupaten Tasikmalaya. Perlakuan yang diterapkan adalah tebal kayu $(2,5 \mathrm{~cm}$, $5 \mathrm{~cm}, 7,5 \mathrm{~cm}$ dan $10 \mathrm{~cm}$ ), immersion time ( 3 hari, 5 hari dan 7 hari), dan konsentrasi bahan pengawet (5\% dan $10 \%$ ). Parameter yang diamati adalah retensi dan penetrasi bahan pengawet. Hasil penelitian menunjukkan bahwa retensi bahan pengawet berbeda nyata pada perlakuan tebal kayu tetapi tidak berbeda nyata pada kedua perlakuan lainnya. Sementara, tingkat penetrasi bahan pengawet tidak berbeda nyata pada semua perlakuan. Retensi dan penetrasi bahan pengawet menunjukkan nilai yang memenuhi persyaratan SNI. Berdasarkan analisis ini, pengawetan kayu tisuk yang disarankan menggunakan BAE adalah konsentrasi bahan pengawet $5 \%$ dengan waktu perendaman 3 hari pada ketebalan $2,5 \mathrm{~cm}, 5 \mathrm{~cm}, 7,5 \mathrm{~cm}$ dan $10 \mathrm{~cm}$.

Kata kunci: Retensi, penetrasi, perendaman dingin, tisuk, pengawetan kayu
\end{abstract}




\section{PENDAHULUAN}

Jenis pohon tisuk (Hibiscus macrophyllus Roxb.) merupakan tanaman dari keluarga Malvaceae dan termasuk ke dalam golongan fast growing species sehingga potensial digunakan dalam pembangunan hutan tanaman, khususnya hutan rakyat. Jenis pohon ini dapat mencapai tinggi 15 $25 \mathrm{~m}$ dan diameter batang $15-25 \mathrm{~cm}$, berbatang lurus, tumbuh liar di Jawa Barat dan Jawa Tengah di bawah ketinggian $800 \mathrm{~m}$ di atas permukaan laut dan dapat ditanam hingga 1400 mdpl. Kemampuan regenerasi alam jenis tisuk sangat tinggi sehingga banyak terdapat anakan alam di bawah tegakan tisuk. Tumbuhan ini mudah dibiakan dengan biji, tetapi tidak dengan cara stek (Heyne, 1987). Penyebarannya di Indonesia terdapat di Kalimantan Selatan, Kalimantan Timur, Jawa dan Sumatera. Di Jawa Barat seperti di daerah Banjarsari, Panawangan, Sukadana masih ditemukan tegakan alam tisuk pada areal masyarakat (Dinas Kehutanan Provinsi Jawa Barat dalam Syamsuwida dkk, 2003).

Kayu tisuk diketahui tahan dalam air, nilai berat jenis kering udara berkisar antara 0,36 - 0,56 dengan rata-rata 0,40 , kayu tersebut tergolong kayu ringan. Sifat kayu ringan tersebut menyebabkan kayu tisuk mudah dikeringkan (Basry dan Rulliaty, 2008). Kayu tisuk termasuk dalam kelas awet dan kelas kuat III - IV (Seng, 1990). Di Jawa kayunya dianggap cocok untuk bangunan rumah, korek api, kulitnya untuk pembuatan tali, untuk bahan anyaman tikar dan lumbung padi. Kulit kayu yang diperuntukan tali maupun benang pancing harus direndam dalam air selama tujuh hari, dikerok dan dikeringkan, bahan serat ini agaknya sangat tahan lama (Heyne 1987).

Berdasarkan penggolongan keawetan kayu di Indonesia (mulai dari kelas I yang paling awet sampai kelas $\mathrm{V}$ yang tidak awet), 85\% dari 4000 jenis terutama jenis kayu yang banyak dikembangkan di hutan rakyat termasuk dalam kelas awet rendah (kelas III, IV dan V). Kenyataan ini ditunjang pula oleh letak geografis Indonesia di khatulistiwa dengan iklim tropisnya yang memungkinkan hadirnya berbagai jenis organisme perusak kayu seperti rayap, bubuk kayu kering, jamur pelapuk (Oey, 1990).

Upaya pencegahan kerusakan kayu sangat penting dalam rangka peningkatan mutu dan masa pakai. Salah satu metoda yang dapat diterapkan dalam memperpanjang umur pakai atau mempertahankan umur komponen kayu adalah melalui penerapan teknologi pengawetan kayu. Dengan demikian, penggunaan kayu-kayu yang diawetkan akan mengurangi laju pergantian kayu sehingga hal ini akan memperlambat atau mengurangi laju penebangan hutan (Barly dan Subarudi, 2010).

Salah satu teknik pengawetan yang sudah dikenal pengawetan dengan bahan pengawet Boric Acid Equivalent (BAE) dengan teknik perendaman dingin. Bahan tersebutdipilih sebagai pengawet kayu pada penelitian ini karena dikenal memiliki beberapa sifat baik, antara lain beracun terhadap jamur dan serangga perusak kayu tetapi tidak berbahaya bagi manusia maupun ternak (Mampe, 2010; Barly et. al., 2011), dapat digunakan dengan proses tekanan maupun dengan proses difusi, tidak korosif terhadap logam, tidak berbau dan tidak merubah warna serta kayu yang diawetkan dapat dicat, diplitur atau direkat dengan baik (Abdurahim, 2008). Hasil penelitian Nugroho dan Darmono (2013) menunjukkan bahwa bahan pengawet BAE efektif untuk pengawetan kayu. Sementara itu teknik pengawetan dengan perendaman dingin merupakan teknik yang relatif mudah dan murah. Menurut Barly dan Krisdianto (2012), proses perendaman dingin memiliki beberapa keuntungan antara lain hanya membutuhkan peralatan sederhana dan murah, mudah dikerjakan/tidak perlu keahlian khusus, dapat diterapkan untuk pengawetan dengan skala kecil. Berdasarkan keuntungan yang ada pada teknik perendaman dingin ini, diharapkan teknik ini lebih mudah untuk dipraktekkan oleh masyarakat luas maupun industri.

Informasi mengenai teknik pengawetan kayu tisuk melalui rendaman dingin masih terbatas. Oleh karena itu kajian mengenai pengawetan kayu tisuk melalui rendaman dingin perlu dilakukan sehingga diperoleh teknik pengawetan kayu tisuk yang relatif mudah dan murah. Penelitian ini bertujuan untuk memperoleh data pengaruh konsentrasi larutan dan lama perendaman dingin terhadap retensi dan penetrasi bahan pengawet BAE pada kayu tisuk dengan beberapa ukuran ketebalan kayu. Hasil penelitian ini diharapkan dapat dijadikan sebagai pertimbangan dalam pengawetan kayu tisuk yang memenuhi standar pengawetan berdasarkan kriteria Standar 
Nasional Indonesia (BSN, 1999). Selain itu, penggunaan bahan pengawet BAE dengan teknik perendaman dingin diharapkan lebih mudah diadopsi oleh masyarakat luas maupun industri karena relatif mudah, murah dan ramah lingkungan.

\section{BAHAN DAN METODE}

\section{A. Lokasi Penelitian}

Penelitian ini dilaksanakan pada bulan Agustus sampai dengan September 2009. Pengambilan sampel pohon dilaksanakan di Desa Sukamulih, Kec. Sariwangi, Kab. Tasikmalaya, Jawa Barat, atau lebih tepatnya pada koordinat $-07^{\circ} 30^{\prime}$ 15,33'LS/108 $05^{\prime}$ 43,22" BT. Perlakuan pengawetan dan pengamatan penetrasi dan retensi dilaksanakan di laboratorium Balai Penelitian Kehutanan Ciamis.

\section{B. Bahan dan Alat Penelitian}

Bahan yang digunakan dalam penelitian ini adalah kayu tisuk (Hibiscus macrophyllus), bahan pengawet kayu BAE (Boric Acid Equivalent) yang berupa campuran boraks $\left(\mathrm{Na}_{2} \mathrm{~B}_{4} \mathrm{O}_{7} \cdot 10 \mathrm{H}_{2} \mathrm{O}\right)$ dan asam borat $\left(\mathrm{H}_{3} \mathrm{BO}_{3}\right)$ dengan pelarut air. Peralatan yang diperlukan yaitu bak perendam, gelas ukur untuk menetapkan konsentrasi larutan bahan pengawet dan gergaji untuk pengambilan contoh kayu yang diawetkan.

\section{Prosedur Kerja}

Rancangan percobaan yang digunakan adalah Rancangan Acak Lengkap (RAL) dengan percobaan faktorial dengan faktor berupa ukuran sortimen atau ketebalan kayu (4 taraf), lama perendaman (3 taraf) dan konsentrasi larutan BAE (2 taraf). Metode pengawetan yang digunakan adalah metode rendaman dingin. Model linier yang digunakan adalah sebagai berikut:

$$
\begin{aligned}
\mathrm{Yijkl}= & \mu+\mathrm{Li}+\mathrm{Bj}+\mathrm{Kk}+\mathrm{LiBj}+\mathrm{LiKk}+\mathrm{BjKk}+ \\
& \mathrm{LiBjKk}+\varepsilon_{\mathrm{ijkl}}
\end{aligned}
$$

Dimana:

$$
\begin{aligned}
\mu & =\text { Rerata umum } \\
\mathrm{Li} & =\text { Efek ketebalan kayu ke } \mathrm{i} \\
\mathrm{Bj} & =\text { Efek lama rendaman ke } \mathrm{j} \\
\mathrm{Kk} & =\text { Efek konsentrasi larutan ke } \mathrm{k}
\end{aligned}
$$

$\mathrm{LiBj}=$ Interaksi ketebalan kayu ke i dan lama rendaman kej

$\mathrm{LiKk}=$ Interaksi ketebalan kayu ke $\mathrm{i}$ dan konsentrasi larutan ke $\mathrm{k}$

$\mathrm{BjKk}=$ Interaksi lama rendaman ke $\mathrm{j}$ dan konsentrasi larutan ke $\mathrm{k}$

$\mathrm{LiBjKk}=$ Inetraksi ketebalan kayu ke i, lama rendaman ke j dan konsentrasi ke $\mathrm{k}$

$\varepsilon_{\mathrm{ijkl}} \quad=$ Random error pada ketebalan kayu ke i, lama rendaman ke $j$ dan konsentrasi larutan ke k

Contoh uji berupa kayu tisuk dipotong dengan empat ukuran sortimen yaitu $2,5 \mathrm{~cm}$ x $5 \mathrm{~cm}$ x $100 \mathrm{~cm} ; 5 \mathrm{~cm} \times 5 \mathrm{~cm} \times 100 \mathrm{~cm} ; 7,5 \mathrm{~cm} \times 5 \mathrm{~cm} \times$ $100 \mathrm{~cm}$; dan $10 \mathrm{~cm} \times 5 \mathrm{~cm} \times 100 \mathrm{~cm}$. Contoh uji disimpan pada suhu kamar sampai kering udara dan ditimbang kemudian direndam ke dalam larutan bahan pengawet pada suhu kamar dengan konsentrasi (berat/volume) 5\% dan 10\%. Perlakuan dibedakan berdasarkan lama perendaman, yaitu selama 3 hari, 5 hari dan 7 hari. Contoh uji setiap perlakuan sebanyak 10 buah sehingga total contoh uji sebanyak 240 buah.

Retensi bahan pengawet diukur dengan cara menimbang berat contoh uji kayu sebelum dan sesudah dilakukan pengawetan. Retensi dihitung sebagai selisih antara berat setelah pengawetan dengan sebelum pengawetan, dibagi dengan volume kayu yang diawetkan/volume contoh uji, dikalikan dengan konsentrasi bahan pengawet yang digunakan, dinyatakan dengan $\mathrm{kg} / \mathrm{m}^{3}$.

Di mana:

$$
R=\frac{B A k-B A w}{V} \times C
$$

$\mathrm{R}=$ Retensi bahan pengawet $\left(\mathrm{kg} / \mathrm{m}^{3}\right)$

$\mathrm{BAk}=$ Berat akhir contoh uji/setelah pengawetan $(\mathrm{kg})$

$\mathrm{BAw}=$ Berat awal contoh uji/sebelum pengawetan (kg)

$\mathrm{V}=$ Volume contoh uji $\left(\mathrm{m}^{3}\right)$

$\mathrm{C}=$ Konsentrasi bahan pengawet $(\%)$

Untuk mengukur dalamnya penetrasi (penembusan) bahan pengawet, setiap contoh uji dipotong melintang pada bagian tengahnya setelah dibiarkan selama dua minggu pada suhu kamar (kering angin). Ke dalaman penetrasi bahan pengawet BAE diamati dengan menyemprotkan atau melaburkan pereaksi boron pada penampang melintang contoh uji hasil pemotongan. Adanya unsur boron ditunjukkan oleh warna merah 
jambu, sedangkan bagian yang tidak mengandung boron berwarna kuning. Penetrasi dihitung dengan mengukur warna merah jambu pada keempat sisi pada permukaan melintang contoh uji, yang kemudian nilainya dirata-ratakan. Uji penetrasi boron terdiri atas (a) $2 \mathrm{~g}$ ekstrak kurkuma dalam $100 \mathrm{ml}$ alkohol (b) $20 \mathrm{ml}$ asam klorida pekat, $80 \mathrm{ml}$ alkohol dan dijenuhkan dengan asam salisilat (13 g per $100 \mathrm{ml})$.

Data retensi dan penetrasi bahan pengawet dianalisis dengan menggunakan uji sidik ragam sesuai dengan rancangan percobaan yang digunakan (Steel dan Torrie, 1960). Nilai retensi dan penetrasi bahan pengawet yang menunjukkan perbedaan nyata diuji lanjut dengan uji Duncan.

\section{HASIL DAN PEMBAHASAN}

\section{A. Lokasi Tempat Tumbuh}

Hasil sidik ragam dari pengaruh ukuran sortimen, lama perendaman dan konsentrasi BAE terhadap retensi pada kayu tisuk disajikan pada
Tabel 1. Berdasarkan Tabel 1, dapat diketahui bahwa perlakuan ukuran sortimen berpengaruh nyata terhadap retensi pada kayu tisuk, sedangkan lama perendaman dan konsentrasi larutan BAE tidak berpengaruh nyata.

Berdasarkan hasil uji lanjut Duncan (Tabel 2)dari dua interaksi yang nyata, diketahui bahwa tingkat retensi bahan pengawet pada tebal kayu 2,5 $\mathrm{cm}$ berbeda nyata dengan ketebalan kayu lainnya, sementara ketebalan kayu $5 \mathrm{~cm} ; 7,5 \mathrm{~cm}$; dan $10 \mathrm{~cm}$ relatif seragam pada taraf kepercayaan 95\%. Tampak pada Gambar 1 bahwa retensi bahan pengawet pada kayu dengan tebal 2,5 cm lebih tinggi dari ketebalan kayu lainnya terutama pada konsentrasi BAE 5\%.

Hasil penelitian ini relatif sama dengan hasil penelitian Barly dan Lelana (2010) pada jenis sengon (Paraserianthes flcataria (L.) Nielsen) dan tusam (Pinus merkusii Jungh. Et de Vries) di mana papan yang lebih tipis menghasilkan tingkat retensi yang lebih tinggi dibanding papan yang lebih tebal. Penelitian menunjukkan bahwa bahan pengawet tidak mampu berpenetrasi pada kayu dengan tebal $>2,5 \mathrm{~cm}$ dengan metode rendaman.

Tabel1. Sidik ragam pengaruh ketebalan kayu, lama perendaman dan konsentrasi pengawet terhadap retensi kayu tisuk

Table 1. Analysis of variance on the wood thickness, soaking time and preservative concentration to the retention of the preservative solutions

\begin{tabular}{|c|c|c|c|c|}
\hline $\begin{array}{c}\text { Sumber keragaman } \\
\text { (Source) }\end{array}$ & $\begin{array}{c}\text { Derajat bebas } \\
\text { (degree of freedom) }\end{array}$ & $\begin{array}{l}\text { Kwadrat tengah } \\
\text { (Mean square) }\end{array}$ & $\begin{array}{l}\text { F Hitung } \\
\text { (F call, })\end{array}$ & $\begin{array}{l}\text { Nilai-p } \\
\text { (p-value) }\end{array}$ \\
\hline Ketebalan kayu (Wood thickness) & 3 & 557,136 & 10,751 & $0,000^{*}$ \\
\hline Lama perendaman (Soaking time) & 2 & 112,824 & 2,177 & $0,116^{\mathrm{ns}}$ \\
\hline $\begin{array}{l}\text { Konsentrasi pengawet (Preservative } \\
\text { contentration) }\end{array}$ & 1 & 161,031 & 3,107 & $0,079^{\mathrm{ns}}$ \\
\hline $\begin{array}{l}\text { Ketebalan kayu (Wood thickness) x } \\
\text { Lama perendaman (Soaking time) }\end{array}$ & 6 & 266,732 & 5,147 & $0,000^{*}$ \\
\hline $\begin{array}{l}\text { Ketebalan kayu (Wood thickness) x } \\
\text { Konsentrasi pengawet (Preservative } \\
\text { contentration) }\end{array}$ & 3 & 329,826 & 6,365 & $0,000^{*}$ \\
\hline $\begin{array}{l}\text { Lama perendaman (Soaking time) } \mathrm{x} \\
\text { Konsentrasi pengawet (Preservative } \\
\text { contentration) }\end{array}$ & 2 & 124,467 & 2,402 & $0,093^{\mathrm{ns}}$ \\
\hline $\begin{array}{l}\text { Ketebalan kayu (Wood thickness) x } \\
\text { Lama perendaman (Soaking time) } \mathrm{x} \\
\text { Konsentrasi pengawet (Preservative } \\
\text { contentration) }\end{array}$ & 6 & 93,413 & 1,803 & $0,100^{\mathrm{ns}}$ \\
\hline
\end{tabular}

Keterangan (Remarks): $*$ = sangat nyata (highly significant); ns $=$ tidak berbeda nyata (not significant) 
Tabe1 2. Uji lanjut Duncan pada retensi bahan pengawet berdasarkan perlakuan tebal kayu Table 2. Duncan test for the retention of the preservative solutions on wood thickness treatment

\begin{tabular}{ccc}
\hline $\begin{array}{c}\text { Ketebalan kayu } \\
\text { (Wood thickness) }\end{array}$ & Subset & $\begin{array}{c}\text { Uji Duncan* } \\
\text { (Duncan test) }\end{array}$ \\
\hline $7.5 \mathrm{~cm}$ & 13,0468 & $\mathrm{~A}$ \\
$10 \mathrm{~cm}$ & 14,5980 & $\mathrm{~A}$ \\
$5 \mathrm{~cm}$ & 15,5247 & $\mathrm{~A}$ \\
$2.5 \mathrm{~cm}$ & 20,1680 & $\mathrm{~B}$ \\
\hline
\end{tabular}

Keterangan (Remark): *huruf yang berbeda menunjukkan perbedaan subset (different letter shows different subset)

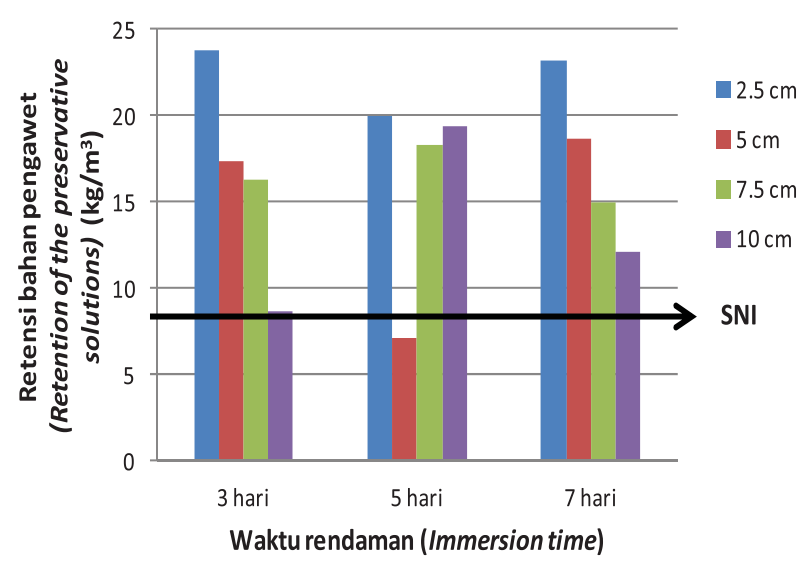

A

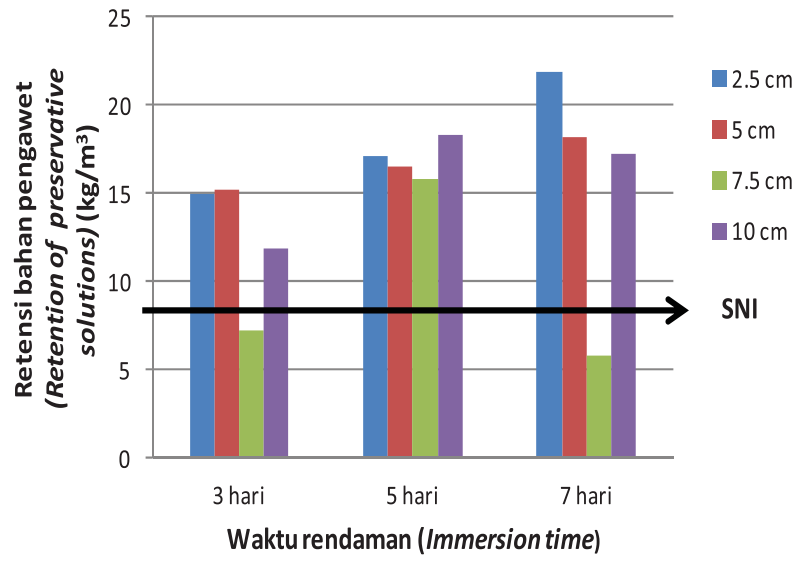

$\mathrm{B}$

Gambar 1. Retensi BAE 5\% (A) dan BAE 10\% (B) pada tisuk Figure 1. BAE retention $5 \%(A)$ and $10 \%(B)$ on the tisuk wood

Gambar 1 menunjukkan bahwa semua perlakuan lama rendaman dan ukuran sortimen menunjukkan nilai retensi BAE yang lebih tinggi dari standar nilai retensi berdasarkan SNI 035010.1-1999 baik pada BAE 5\% maupun BAE $10 \%$, kecuali pada perlakuan BAE $5 \%$ lama rendaman 5 hari pada ukuran sortimen $5 \mathrm{~cm} \times 5$ $\mathrm{cm} \times 100 \mathrm{~cm}$ dan pada perlakuan BAE 10\% lama rendaman 3 hari dan 7 hari, pada ukuran sortimen $7,5 \mathrm{~cm} \times 5 \mathrm{~cm} \times 100 \mathrm{~cm}$. Nilai retensi yang masih di bawah SNI (BSN, 1999) pada konsentrasi yang lebih tinggi dan pada lama rendaman yang lebih lama mengindikasikan bahwa pengawetan dengan cara perendaman pada perlakuan tersebut tidak dapat berpenetrasi lebih jauh sehingga tingkat retensinya rendah.

Berdasarkan SNI 03-5010.1-1999 (BSN, 1999), persyaratan retensi bahan pengawet sebesar 8,0 $\mathrm{kg} / \mathrm{m}^{3}$. Hal ini menunjukkan bahwa untuk menghasilkan retensi dengan nilai minimal 8,0 $\mathrm{kg} / \mathrm{m}^{3}$ cukup dengan mengawetkan kayu tisuk dengan larutan BAE $5 \%$ selama 3 hari untuk kayu dengan tebal $2,5 \mathrm{~cm}, 5 \mathrm{~cm}, 7,5 \mathrm{~cm}$ dan $10 \mathrm{~cm}$.
Hasil sidik ragam pengaruh ukuran sortimen, lama perendaman dan konsentrasi BAE terhadap penetrasi pada kayu tisuk (Tabel 3). Berdasarkan Tabel 3, dapat diketahui bahwa perlakuan ukuran sortimen, lama perendaman dan konsentrasi BAE tidak berpengaruh nyata terhadap nilai penetrasi, namun interaksinya ada yang berpengaruh nyata, yaitu pada interaksi perlakuan ketebalan kayu dengan lama perendaman, ketebalan kayu dengan konsentrasi pengawet, dan ketebalan kayu dengan lama perendaman dan konsentrasi pengawet.

Tingkat penetrasi BAE pada tisuk yang dihasilkan dari semua perlakuan memenuhi standar SNI. Gambar 2 menunjukkan baik pada konsentrasi BAE 5\% maupun BAE 10\%, semua perlakuan lama perendaman dan ukuran sortimen menghasilkan nilai penetrasi bahan pengawet yang lebih tinggi dari nilai penetrasi minimal menurut SNI 03-5010.1-1999 (BSN, 1999), yaitu sebesar 5 $\mathrm{mm}$ atau $0,5 \mathrm{~cm}$. Hal ini menunjukkan bahwa untuk menghasilkan penetrasi dengan nilai minimal 0,5 cm cukup dengan mengawetkan kayu tisuk dengan larutan BAE 5\% selama 3 hari baik 
untuk kayu dengan ketebalan 2,5 cm, $5 \mathrm{~cm}, 7,5 \mathrm{~cm}$ maupun $10 \mathrm{~cm}$.

Tingkat penetrasi BAE pada tisuk yang dihasilkan dari semua perlakuan memenuhi standar SNI. Gambar 2 menunjukkan baik pada konsentrasi BAE 5\% maupun BAE 10\%, semua perlakuan lama perendaman dan ukuran sortimen menghasilkan nilai penetrasi bahan pengawet yang lebih tinggi dari nilai penetrasi minimal menurut SNI03-5010.1-1999 (BSN, 1999), yaitu sebesar $0,5 \mathrm{~cm}$. Hal ini menunjukkan bahwa untuk menghasilkan penetrasi dengan nilai minimal $0,5 \mathrm{~cm}$ cukup dengan mengawetkan kayu tisuk dengan larutan BAE 5\% selama 3 hari baik untuk kayu dengan ketebalan $2,5 \mathrm{~cm}, 5 \mathrm{~cm}, 7,5 \mathrm{~cm}$ maupun $10 \mathrm{~cm}$.

Tabe13. Sidik ragam pengaruh ketebalan kayu, lama perendaman dan konsentrasi pengawet terhadap penetrasi kayu tisuk

Table 3. Analysis of variance on the wood thickness, soaking time and preservative concentration to the penetration of the preservative solutions

\begin{tabular}{|c|c|c|c|c|}
\hline $\begin{array}{c}\text { Sumber } \\
\text { keragaman } \\
\text { (Source) }\end{array}$ & $\begin{array}{l}\text { Derajat bebas } \\
\text { (degree of freedom) }\end{array}$ & $\begin{array}{l}\text { Kwadrat tengah } \\
\text { (Mean square) }\end{array}$ & $\begin{array}{l}\text { F Hitung } \\
\text { (F cal.) }\end{array}$ & $\begin{array}{l}\text { Nilai-p } \\
(p-v a l u e)\end{array}$ \\
\hline Ketebalan kayu (Wood thickness) & 3 & 0,711 & 1,444 & $0,231 \mathrm{~ns}$ \\
\hline Lama perendaman (Soaking time) & 2 & 0,205 & 0,417 & $0,660 \mathrm{~ns}$ \\
\hline $\begin{array}{l}\text { Konsentrasipengawet (Preservative } \\
\text { contentration) }\end{array}$ & 1 & 1,119 & 2,273 & $0,133 \mathrm{~ns}$ \\
\hline $\begin{array}{l}\text { Ketebalan kayu (Wood thickness) x } \\
\text { Lama perendaman (Soaking time) }\end{array}$ & 6 & 4,835 & 9,824 & $0,000^{*}$ \\
\hline $\begin{array}{l}\text { Ketebalan kayu (Wood thickness) x } \\
\text { Konsentrasi pengawet (Preservative } \\
\text { contentration) }\end{array}$ & 3 & 4,046 & 8,221 & $0,000^{*}$ \\
\hline $\begin{array}{l}\text { Lama perendaman (Soaking time) } \\
\text { x Konsentrasi pengawet } \\
\text { (Preservative contentration) }\end{array}$ & 2 & 0,631 & 1,282 & $0,280 \mathrm{~ns}$ \\
\hline $\begin{array}{l}\text { Ketebalan kayu (Wood thickness) } \mathrm{x} \\
\text { Lama perendaman(Soaking time) } \mathrm{x} \\
\text { Konsentrasi pengawet (Preservative } \\
\text { contentration) }\end{array}$ & 6 & 2,146 & 4,361 & $0,000^{*}$ \\
\hline
\end{tabular}

Keterangan (Remarks): * = sangat nyata (bighly significant); ns $=$ tidak berbeda nyata (not significant)

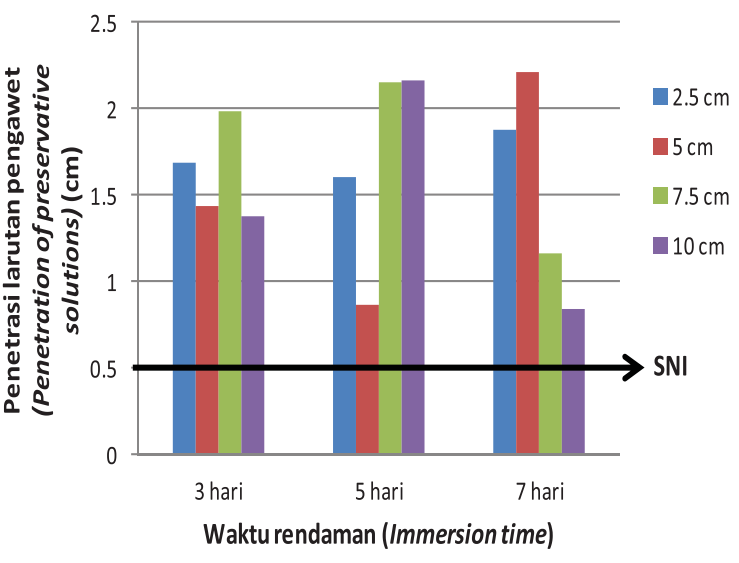

A

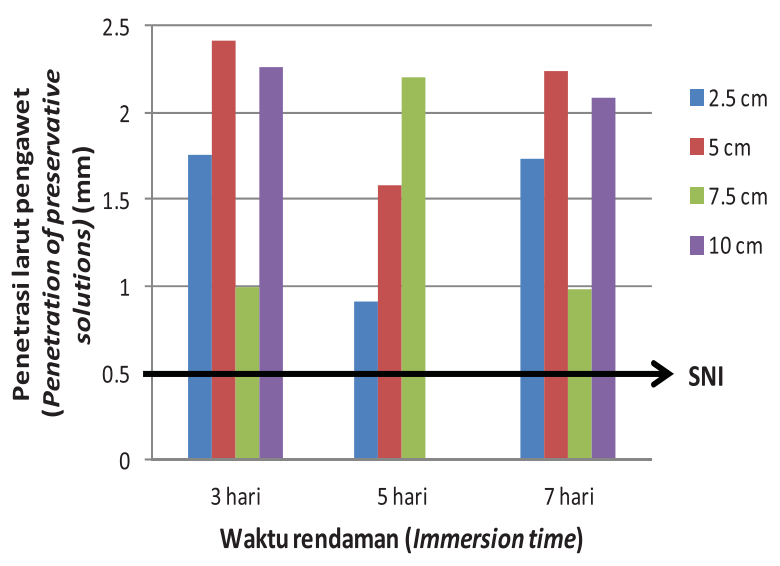

$\mathrm{B}$

Gambar 2. Penetrasi BAE 5\% (A) dan BAE 10\% (B) pada tisuk Figure 1. BAE penetration $5 \%(A)$ and $10 \%(B)$ on the tisuk wood 
Tingkat penetrasi bahan pengawet BAE pada kayu tisuk sebagaimana ditunjukkan pada Gambar 2 tampak tidak konsisten pada perlakuan yang diujicobakan. Pada perlakuan lama perendaman, bertambahnya waktu perendaman tidak serta merta menunjukkan peningkatan retensi bahan pengawet (meskipun faktor interaksi dapat berpengaruh). Pada ketebalan kayu $7,5 \mathrm{~cm}$ dengan konsentrasi BAE $5 \%$ maupun $10 \%$, misalnya, tingkat penetrasi pada rendaman 5 hari lebih tinggi dibanding pada rendaman 3 hari, tetapi pada rendaman 7 hari justru lebih rendah dari lama perendaman 3 dan 5 hari. Sementara pada perlakuan ketebalan kayu juga tidak menunjukkan penurunan ataupun peningkatan nilai penetrasi yang konsisten dengan bertambah tebal ukuran kayu.

Hasil penelitian ini berbeda dengan hasil penelitian Barly dan Lelana (2010) pada jenis sengon (Paraserianthes falcataria (L.) Nielsen) dan tusam (Pinus merkusii Jungh et de Vries) di mana konsentrasi larutan, lama perendaman dan ketebalan kayu pada jenis yang sama berpengaruh nyata terhadap retensi dan penembusan bahan pengawet dengan kecenderungan yang konsisten. Pada sengon dan pinus, tingkat retensi dan penetrasi meningkat dengan bertambahnya waktu perendaman. Demikian juga dengan peningkatan konsentrasi bahan pengawet BAE yang cenderung menghasilkan peningkatan retensi dan penembusan bahan pengawet.

Tingkat penetrasi (dan retensi) bahan pengawet yang tidak konsisten antar perlakuan pada penelitian ini diduga karena keadaan kayu yang bervariasi pada saat dilakukan pengawetan dan berperan dalam menentukan hasil pengawetan kayu. Menurut Martawijaya dan Barly (1982), tingkat penembusan bahan pengawet ditentukan oleh jenis kayu, keadaan kayu pada saat diawetkan dan teknik dan bahan pengawet yang digunakan. Keadaan kayu tisuk pada saat diawetkan dalam penelitian ini diduga cukup beragam karena variasi individu yang mungkin ada pada jenis tisuk. Sebagaimana menurut Zobel dan Buijtenen (1989); Brown et al. (1952), variasi sifat kayu dalam satu spesies dapat disebabkan karena perbedaan wilayah geografis dan tempat tumbuh, perbedaan umur, perbedaan posisi ketinggian dan posisi lateral dalam batang, dan perbedaan kecepatan tumbuh. Dalam penelitian ini, sampel yang terpilih secara acak ini dapat saja bervariasi dalam umur, perbedaan posisi dalam batang baik arah aksial maupun radial, ataupun perbedaan sifat kayu yang mungkin timbul akibat kayu reaksi atau adanya bagian di sekitar mata kayu. Keadaan sampel kayu yang mungkin bervariasi tersebut dapat mempengaruhi nilai penetrasi dan retensi bahan pengawet selama proses pengawetan.

Namun demikian, nilai retensi dan penetrasi pada kayu tisuk yang dihasilkan dalam penelitian ini cukup menjadi dasar bahwa perlakuan perendaman dingin dengan bahan pengawet $\mathrm{BAE}$ $5 \%$ selama 3 hari cukup untuk memenuhi standar retensi dan penetrasi menurut SNI (1999). Perlakuan tersebut bahkan berlaku untuk keadaan kayu tisuk dengan kemungkinan berbagai variasi sifat kayu akibat perbedaan umur, tingkat pertumbuhan ataupun kedudukan dalam pohon (aksial dan radial). Dengan demikian dalam pemanfaatan kayu tisuk lebih luas, perlu memperhatikan persyaratan tingkat retensi dan penetrasi sesuai dengan penggunaannya. Menurut Abdurrahim (2008), pemakaian kayu di bawah atap yang berhubungan dengan tanah memerlukan retensi dan penetrasi yang lebih besar. Demikian juga menurut Tamblyn et al. (1968) yang menyarankan penetrasi hingga $12 \mathrm{~mm}$ pada kayu bangunan tropis.

\section{KESIMPULAN DAN SARAN}

\section{A. Kesimpulan}

Tingkat retensi BAE sebagai bahan pengawet pada kayu tisuk memenuhi standar SNI pada sebagian besar perlakuan kecuali pada ketebalan kayu $5 \mathrm{~cm}$ pada konsentrasi BAE $5 \%$ dengan lama perendaman 5 hari, serta ketebalan kayu $7,5 \mathrm{~cm}$ pada konsentrasi BAE 10\% dengan lama perendaman 3 dan 7 hari. Tingkat penetrasi bahan pengawet BAE pada kayu tisuk memenuhi standar SNI pada semua perlakuan, yaitu penetrasi minimal $5 \mathrm{~mm}$.

\section{B. Saran}

Pada penelitian lebih lanjut, disarankan untuk dilakukan penelitian teknik pengawetan yang sama pada jenis tisuk, tetapi dengan konsentrasi larutan pengawet yang lebih rendah dari $5 \%$ dan perendaman yang lebih singkat dari 3 hari. Hal ini mengingat bahwa perlakuan konsentrasi dan lama 
perendaman yang paling kecil (konsentrasi $5 \%$ dan perendaman 3 hari) dalam penelitian ini sudah memenuhi retensi dan penetrasi berdasarkan SNI.

\section{DAFTAR PUSTAKA}

Abdurrahim, S., (2008). Penggunaan bahan pengawet kayu di Indonesia. Buletin Hasil Hutan. Vol. 14 No. 2. Hal 107-115. Bogor: Pusat Litbang Hasil Hutan.

Barly dan Krisdianto. (2012). Petunjuk Teknis Pengawetan Kayu Karet. Direktorat Jenderal Bina Usaha Kehutanan (BUK). Jakarta. Kementerian Kehutanan.

Barly dan N.E. Lelana. (2010). Pengaruh ketebalan kayu, Konsentrasi larutan dan lama perendaman terhadap hasil pengawetan kayu. Jurnal Penelitian Hasil Hutan Vol. 28. No.1. Hal 1-8. Bogor: Pusat Litbang Hasil Hutan.

Barly dan Subarudi. (2010). Kajian industri dan kebijakan pengawetan kayu: sebagai upaya mengurangi tekanan terhadap hutan. Jurnal Analisis Kebijakan Kebutanan Vol T, No.1, April 2010: 63-80. Bogor: Pusat Penelitian Perubahan Iklim dan Kebijakan Kehutanann.

Barly, A. Ismanto dan D. Martono. (2011). Dayaguna campuran soda abu - boraks sebagai anti jamur biru dan rayap. Jurnal Penelitian Hasil Hutan Vol. 29 No. 2, Juni 2011: 179-188. Bogor: Pusat Litbang Hasil Hutan.

Basry, E dan S. Rulliaty. (2008). Pengaruh sifat fisik dan anatomi terhadap sifat pengeringan enam jenis kayu. Jurnal Penelitian Hasil Hutan: 1-16. Bogor: Pusat Litbang Hasil Hutan.

Brown, H.P., A.J. Panshin, and C.C. Forsaith. (1952). Texbook of Wood Technology, Vol. II. New York: McGraw-Hill.

BSN, (1999). Pengawetan Kayu untuk Perumahan dan Gedung. Standar Nasional Indonesia
(SNI) 03-5010.1-1999. Jakarta: Badan Standarisasi Nasional.

Heyne K. (1987). Tumbuhan Berguna Indonesia III. Badan Penelitian dan Pengembangan Kehutanan, Jakarta: Departemen Kehutanan.

Mampe, C. D. (2010). Effectiveness and Uses of Barate. http://www.environment sensitive.com/effectiveusesofborate.htm. Diakses tanggal 17 Oktober 2013.

Martawijaya, A. dan Barly. (1982). Resistensi kayu Indonesia terbadap imprgnasi dengan bahan pengawet CCA. Pengumuman No. 5. Balai Penelitian Hasil Hutan. Bogor

Nugroho, N.K.C dan M.T. Darmono. (2013). Efektivitas pengawetan kayu terhadap serangan rayap menggunakan campuran boraks dengan asam borat. Thesis. Program Studi Teknik Sipil, Fakultas Teknik, Universitas Negeri Yogyakarta. http://eprints.uny.ac.id/ $\underline{10020 / .}$. Diakses pada tanggal 17 Oktober 2013

Oey, D.S. (1990). Spesific grafity of Indonesian woods and its significance for practical use, Diterjemahkan oleh Suwarsono P,H, Bogor. Indonesia: Pusat Penelitian dan Pengembangan Hasil Hutan, Departemen Kehutanan Indonesia.

Steel, R.G.D and J.H. Torrie. (1960). Principles and Procedures of Statistics. New York: McGraw.

Syamsuwida, D., N. Yuniarti, R. Kurniaty dan Z. Abidin. (2003). Teknik Penanganan Benih Ortodok. Buku I. Bogor: Balai Penelitian dan Pengembangan Teknologi Perbenihan.

Tamblyn, N. S.J. Colwell and N. Vickers. (1968). Preservative Treatment of Tropical Building Timbers by a Dip Diffusion Process. $9^{\text {th }}$ British Commonwealth Forestry Conference 1968. Australia.

Zobel, J.B. and J.P.V. Buijtenen (1989). Wood Variation. John Willey \& Sons. pp. 231-240. 